\title{
Social Adjustment of Adolescents with Hearing Impairment
}

\author{
Debby A. Daulay, Ade Rahmawati \\ Department of Developmental Psychology, \\ University of Sumatera Utara, Medan, Indonesia \\ debby_anggraini@usu.ac.id,ade.rahmawati@usu.ac.id,
}

\begin{abstract}
The aim of this research is to describe social adjustment of adolescents with hearing impairment. Adolescents with hearing impairment have difficulty in producing sounds or voice of language that ultimately have an impact on the process of communication in everyday life. Based on these conditions, the task of development is to fulfill social adjustment which requires a major effort to avoid some negative impacts. The research uses social adjustment theory from Schneider (1964) which refers to the real appearance through attitudes and behavior, self-adjustment to a group of people, social attitudes, and personal satisfaction. Sampling technique in this research is the cluster random sampling, with 161 adolescents as subject range from 11-21 years old. Data analysis method used is descriptive analysis. The result of the data analysis showed that most of adolescents with hearing impairment in Special-Needs School in City of Medan have their social adjustment in medium category with percentage of $73 \%$. In addition, the results are obtained from the additional form of an overview of social adjustment based on age and gender.
\end{abstract}

Keywords: social adjustment; adolescents with hearing impairment

\section{INTRODUCTION}

One of disabilities that still has the potential to be developed to its full potential is deafness (in Putra, 2013). Deafness is a condition that causes a person could not be able to catch a variety of stimuli, especially through the senses of hearing (Somantri, 2007). The deaf have particular characteristics that are different from normal people. Van uden (in Heryati, 2010) said that deaf people tend to be egocentric, have more anxiety feelings, more dependent on others especially those already familiar, difficult to be distracted, more focus on concrete things, poor fantasy, nature plain, simple but tend to be irritable or quick to take offense, and lacked the concept of the relationship, so that they often impressed as an elusive character.

Generally when entering adolescence, deaf children will experience more severe problems, because they tend more often to explore the world and they are required to be able to interact with the general public. According to Schneiders (1964), social adjustment can be defined as the ability or capacity of the individual to react effectively and appropriately for the reality of the situation, and social relations so that the demands of social life are met in a way that is acceptable and satisfactory. For deaf adolescents who have various limitations, this certainly feared could trigger the emergence of various problems in young deaf, especially in terms of social adjustment itself.

\section{A. Social Adjustment}

Schneiders (1964) defines social adjustment as "the capacity to react adequately to social realities, situation and relations". Social adjustment indicates the ability or capacity of the individual to react effectively and reasonable on social reality, situations and social relations. More specifically, Schneiders (1964) state that social adjustment is the ability or capacity of the individual to react effectively and appropriately for the reality of the situation, and social relations, so that the demands of social life are met in a way that is acceptable and satisfactory.

There are four criteria to determine the extent of a person's social adjustment achieved a good measure:

a) Real appearance through the attitudes and real behavior

If the social behavior of individuals in accordance with the standards of a group or meet the expectations of the group, then the 
individual will be accepted as a member of the group. It can be seen from self-actualization, which is a process to be ourselves and be able to develop the properties and potential; interpersonal relationship skills, and be able to open himself to others, are willing to accept and provide knowledge or information to others.

b) Social adjustment to various groups

Individuals can adapt well to a variety of groups, both peer groups and groups of adults. It can be realized in cooperation with a group whose members support each other to achieve good results; carry out the responsibilities of the well, sharing, and motivated to do good and loyalty in friendship.

c) Social attitudes

Individuals will be able to adjust well socially if it is able to show good behavior towards others, participate in social participation, as well as participate in group activities. It can be realized by participating in social activities in the community, show empathy and mutual respect.

d) Personal satisfaction

Individuals should be able to adapt to the social, able to feel satisfied with their social contacts and able to participate in various social situations. It can be seen through the self-confidence, self-discipline and life meaningful and purposeful.

\section{B. Adolescence}

Adolescence is a period of transition in human life span that connects childhood to adulthood. The term youth or adolescence comes from the Latin word, namely adolescere (the noun, adolescentia, which means teens) which means "growing" or "grow up", which has a broader meaning includes mental maturity, emotional, social and physical. Early adolescence begins when the child has sexual maturity and ended up as a teenager has a legal maturity.

Early adolescence is divided into two phases: early adolescence and late adolescence. Early adolescence ranged in age from 13 to 16 years, and late adolescence from age 16 to 18 years (Hurlock, 1997). While Monks, et al (2006) found that in general, adolescence ranged from 12 to 21 years of age, namely:

1. Early adolescence: 12-15 years, generally referred to as puberty, which are known by their sexual maturity that impact on their psychosocial development

2. The middle adolescence : $15-18$ years, and

3. Late adolescence: 18-21 years old, the age when a person has a right as a citizen, and has certain obligations and responsibilities, and are no longer dependent on their parents

According to Piaget (in Hurlock, 1997) psychologically, adolescence is the age at which individuals integrate into adult society, feel that they are not under the adults, but on par with them, at least about individual rights.

Definitions and classification of hearing impairment

Medically, hearing impairment is lack or loss of ability to hear is caused by damage of part or all of the tools of hearing or often called deafness (Sastrawinata, 1977). According to Somantri (2007), hearing impairment is hearing loss, so that individuals are not able to capture a variety of stimuli through the senses of hearing.

A person considered to have normal hearing when the test results of hearing is $0 \mathrm{~dB}$. This condition is rare, almost non-existent, because every people must have experienced the setback in terms of the sharpness of hearing. Therefore, based on the values of tolerance threshold of hearing, someone who lost hearing acuity to $0-20 \mathrm{~dB}$ are still considered to be normal, because the impact is not significant (Effendi, 2006).

Hallahan and Kaufman (1991) defines hearing impairment as a general term that indicates trouble hearing from mild to severe, and is classified as deaf (deaf) and hearing loss (hard of hearing). According to ISO (International Standard Organization), someone who is categorized as deaf, when it loses the ability to hear $70 \mathrm{~dB}$ or more, making it difficult to understand the speech of others, even if using a hearing aid or without the use of hearing aids. While someone who is hard of hearing are categorized as people who have lost the ability to hear between 35$69 \mathrm{~dB}$, making it difficult to hear the voices of others, but can still be treated with hearing aids. 


\section{MATERIAL AND METHODS}

This research is a descriptive study that aims to see the description of social adjustment of adolescent in Special-Needs School in City of Medan. According to Azwar (1999), descriptive research is a method of describing the facts accurately and systematically, but does not intend to explain, to test the hypothesis, make predictions and implications. Descriptive method aims to describe a phenomenon that occurs, without any intention to draw conclusions that apply in general (Hadi, 2000).

The respondents of this study are 161 hearing impairment adolescents from Special-Needs School in City of Medan. The sampling technique is the cluster random sampling.

\section{RESULT AND DISCUSSION}

The research subjects in this study are 161 adolescents with hearing impairment in SpecialNeeds School in City of Medan. Here will be described an overview of the research subjects:

Description of study subject based on adolescent development phase

In this study, the adolescent category is divided into three stages of development, namely, early adolescents (aged 11-14 years), middle adolescents (aged 15-17 years) and late adolescents (aged 18-21 years), which can be seen in the following table:

Table I. Overview research subjects based adolescence development phase

\begin{tabular}{|l|c|c|}
\hline Stage of adolescent development & Amount & Percentage \\
\hline Early adolescents (11-14 years) & 55 & $34 \%$ \\
\hline The middle adolescence & 62 & $38.5 \%$ \\
$(15-17$ years $)$ & & \\
\hline Late adolescence (18-21 years) & 44 & $27.5 \%$ \\
\hline TOTAL & 161 & $100 \%$ \\
\hline
\end{tabular}

In table I, we can see the number of subject are classified as early adolescence there are 55 (34\%), middle adolescence there are $62(38.5 \%)$ and late adolescents are $44(27.5 \%)$. Thus if it is sorted, then the subject is mostly in the category of middle adolescent, early teens and the next is at least late adolescence.

Overview research subjects by gender

In this study, a group of teenage boys there are 78 , and a group of teenage girls there are 83. It can be concluded that the number of teenage girls are more than the number of the boys. This can be seen in the following table:

Table II. Overview research subjects by gender

\begin{tabular}{|l|l|l|}
\hline \multicolumn{1}{|c|}{ Gender } & \multicolumn{1}{|c|}{ Amount } & Percentage \\
\hline Boy & 78 & $48.5 \%$ \\
\hline Girl & 83 & $51.5 \%$ \\
\hline Total & 161 & $100 \%$ \\
\hline
\end{tabular}

In table II, we can see the number of subjects classified as teenage boys are as many as 78 people (48.5\%), while among girls 83 people (51.5\%). Thus if it is sorted, then the number of subjects was highest among girls.

The Comparison of Hypothetical and Empirical Mean of Mean of Research Data

Here is a description of the social adjustment of adolescents with hearing impairment in SpecialNeeds School in City of Medan:

\section{The Mean comparison of research data}

Based on the calculations the empirical data of 191 research subjects, obtained a minimum score is 32 and a maximum score is 55; with a Mean of 44.67 and a standard deviation is 4.67. Based on hypothetical data calculation, obtained a minimum score is 16 and a maximum score of 64; with a mean of 40 and a standard deviation is 8 . This data can be seen in the following table: 
Table III. The mean comparison of research data

\begin{tabular}{|l|l|l|l|l|l|l|l|l|l|l|}
\hline \multicolumn{5}{|c|}{ Empirical } & \multicolumn{5}{c|}{ Hypothetical } \\
\hline & $\mathrm{N}$ & $\begin{array}{l}\text { Mi } \\
\mathrm{n}\end{array}$ & $\begin{array}{l}\mathrm{M} \\
\mathrm{ax}\end{array}$ & $\begin{array}{l}\text { Me } \\
\text { an }\end{array}$ & $\mathrm{SD}$ & $\mathrm{N}$ & $\begin{array}{l}\text { Mi } \\
\mathrm{n}\end{array}$ & $\begin{array}{l}\mathrm{M} \\
\mathrm{ax}\end{array}$ & $\begin{array}{l}\text { Me } \\
\text { an }\end{array}$ & $\begin{array}{l}\mathrm{S} \\
\mathrm{D}\end{array}$ \\
\hline $\begin{array}{l}\text { Social } \\
\text { Adjust } \\
\text { ment }\end{array}$ & 19 & 32 & 55 & $\begin{array}{l}44 . \\
74\end{array}$ & $\begin{array}{l}4.6 \\
7\end{array}$ & $\begin{array}{l}19 \\
1\end{array}$ & 16 & 64 & 40 & 8 \\
\hline
\end{tabular}

In table III, it can be seen that at the empirical mean of social adjustment is greater than the hypothetical $(44.74>40)$; so it can be concluded that the social adjustment of the research subjects was higher than the general population. Based on the comparison standard deviation, it can be seen that the standard deviation of the empirical data is smaller than the hypothetical $(4.67<8)$; it can be concluded that the variations in social adjustment scores are still likely to be low or tend to be uniform.

\section{The Categorization of Social Adjustment}

Social adjustment categorization in this study is based on the data and hypothetical data, which is divided into three groups: low, medium and high. This can be seen in the following table:

Table IV. Categorization of social adjustment formula

\begin{tabular}{|l|l|l|}
\hline Variable & \multicolumn{1}{|c|}{ Range } & Categorization \\
\hline \multirow{4}{*}{$\begin{array}{l}\text { Social } \\
\text { Adjustment }\end{array}$} & $\mathrm{x}<$ mean-1SD & Low \\
\cline { 2 - 4 } & $\begin{array}{l}\text { mean-1SD } \leq \mathrm{x}< \\
\text { mean+1SD }\end{array}$ & Average \\
\cline { 2 - 3 } & $\mathrm{x} \geq$ mean+1SD & High \\
\hline
\end{tabular}

Based on the norms of categorization in table IV and a description of a hypothetical value of social adjustment in table III, the following will describe the categorization of social adjustment:
Table V. Categorization of social adjustment

\begin{tabular}{|c|c|c|c|c|}
\hline Variable & Range & Categorization & Frequency & $\begin{array}{c}\text { Percentage } \\
(\%)\end{array}$ \\
\hline \multirow{3}{*}{$\begin{array}{l}\text { Social } \\
\text { Adjustment }\end{array}$} & $x<32$ & Low & 0 & $0 \%$ \\
\hline & $\begin{array}{l}32 \leq \\
x<48\end{array}$ & Average & 117 & $73 \%$ \\
\hline & $\begin{array}{l}x \geq \\
48\end{array}$ & High & 44 & 27 \\
\hline
\end{tabular}

Based on table $\mathrm{V}$, the variables of social adjustment, no subject who belong to the lower category; $73 \%$ of is classified into the moderate and $27 \%$ is classified into a higher category. In other words, it can be concluded that the largest group is in the moderate category of social adjustment.

\section{The Comparison Mean of research data based on Aspect of Social Adjustment}

Social Adjustment consists of several aspects, namely the real appearance, the adjustment group, social attitudes and personal satisfaction, which can be seen below:

Table VI. The comparison mean of research data based on aspect of social adjustment

\begin{tabular}{|c|l|l|l|l|}
\hline Variable & \multicolumn{1}{|c|}{ Aspect } & Empirical & Hypothetical & Comparison \\
\hline & $\begin{array}{l}\text { Real } \\
\text { appearance }\end{array}$ & 10 & 10.39 & $\begin{array}{l}\text { Hypothetical } \\
\text { < Empirical }\end{array}$ \\
\cline { 2 - 5 } & $\begin{array}{l}\text { Adjustment } \\
\text { group }\end{array}$ & 10 & 12.01 & $\begin{array}{l}\text { Hypothetical } \\
\text { < Empirical }\end{array}$ \\
\cline { 2 - 5 } $\begin{array}{l}\text { Social } \\
\text { Adjustment }\end{array}$ & $\begin{array}{l}\text { Social } \\
\text { attitudes }\end{array}$ & 10 & 11.42 & $\begin{array}{l}\text { Hypothetical } \\
\text { < Empirical }\end{array}$ \\
\cline { 2 - 5 } & $\begin{array}{l}\text { Personal } \\
\text { satisfaction }\end{array}$ & 10 & 10.9 & $\begin{array}{l}\text { Hypothetical } \\
\text { < Empirical }\end{array}$ \\
\hline
\end{tabular}

Based on table VI, the empirical mean of the four aspects of social adjustment variable was greater than the hypothetical. It can be concluded that statistically, the average value of the four aspects of the social adjustment variables higher than in the general

population.

An overview of research subjects based its aspects:

1. The research subject is based on four aspects of the social adjustment overview. 
4 aspects of social adjustment in this study based on data hypothetical, which are divided into three groups, namely the low, medium and high. This categorization can be seen as follows:

Table VII. Social adjustment categorization based on aspect

\begin{tabular}{|c|c|c|c|c|}
\hline Aspect & Formula & $\begin{array}{c}\text { Categorizatio } \\
\mathrm{n}\end{array}$ & Amount & $\begin{array}{c}\text { Percentag } \\
\text { e } \\
(\%)\end{array}$ \\
\hline \multirow{3}{*}{$\begin{array}{l}\text { Real } \\
\text { Appea } \\
\text { rance }\end{array}$} & $X<8$ & Low & 9 & 5.6 \\
\hline & $8 \leq X<12$ & Average & 103 & 64 \\
\hline & $X \geq 12$ & High & 49 & 30.4 \\
\hline \multirow{3}{*}{$\begin{array}{l}\text { Adjust } \\
\text { ment } \\
\text { Group }\end{array}$} & $X<8$ & Low & 6 & 3.7 \\
\hline & $8 \leq X<12$ & Average & 56 & 34.8 \\
\hline & $X \geq 12$ & High & 99 & 61.5 \\
\hline \multirow{3}{*}{$\begin{array}{l}\text { Social } \\
\text { Attitu } \\
\text { des }\end{array}$} & $X<8$ & Low & 5 & 3.1 \\
\hline & $8 \leq X<12$ & Average & 83 & 51.5 \\
\hline & $x \geq 12$ & High & 73 & 45.4 \\
\hline \multirow{3}{*}{$\begin{array}{l}\text { Person } \\
\text { al } \\
\text { Satisfa } \\
\text { ction }\end{array}$} & $X<8$ & Low & 5 & 3.1 \\
\hline & $8 \leq X<12$ & Average & 102 & 63.3 \\
\hline & $x \geq 12$ & High & 54 & 33.6 \\
\hline
\end{tabular}

Based on table VII, it can be seen that in the aspect of real appearance, the highest number is in the medium (64\%); at number two is in the high (30.4\%); and the lowest is in the low category (5.6\%). In the aspect of the adjustment group, the highest number is in the high (61.5\%); in the second position is in the middle (34.8\%); and the last position is in the low category (3.7\%). In the aspect of social attitudes, the highest number is in the middle (51.5\%); second place is in the high (45.4\%); and there are lows in the low category $(3.1 \%)$. In the aspect of Personal Satisfaction, the highest number is in the middle (63.3\%); second place is in the high (33.6\%); and the last position is in the low category (3.1\%).

2. The mean comparison of research data based on adolescents developmental phase

The following describes the way of study participants, by adolescents developmental phase, based on the comparison of the hypothetical and empirical mean.

Table VIII. The mean comparison of research data based on adolescents developmental phase

\begin{tabular}{|c|c|c|c|c|c|}
\hline \multirow[t]{2}{*}{$\begin{array}{l}\text { Variable } \\
\text { and } \\
\text { Aspect }\end{array}$} & $\begin{array}{l}\text { Hypothe } \\
\text { tical }\end{array}$ & $\begin{array}{l}\begin{array}{l}\text { Early } \\
\text { Adolesc } \\
\text { ence }\end{array} \\
11-14 \\
\text { Years } \\
\text { old }\end{array}$ & $\begin{array}{l}\text { The } \\
\text { middle } \\
\text { adolesc } \\
\text { ence } \\
15-17 \\
\text { Years } \\
\text { old }\end{array}$ & 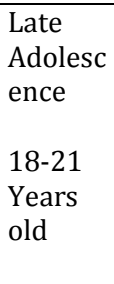 & \multirow[t]{2}{*}{$\begin{array}{l}\text { Compari } \\
\text { son }\end{array}$} \\
\hline & & (M) & (M) & (M) & \\
\hline $\begin{array}{l}\text { Social } \\
\text { Adjustm } \\
\text { ent }\end{array}$ & 40 & 43.96 & 44.79 & 45,63 & $\begin{array}{l}\text { Hypothe } \\
\text { tical < } \\
\text { Empiric } \\
\text { al }\end{array}$ \\
\hline $\begin{array}{l}\text { Real } \\
\text { Appeara } \\
\text { nce }\end{array}$ & 10 & 11.76 & 11.70 & 11.11 & $\begin{array}{l}\text { Hypothe } \\
\text { tical < } \\
\text { Empiric } \\
\text { al }\end{array}$ \\
\hline $\begin{array}{l}\text { Adjustm } \\
\text { ents } \\
\text { Group }\end{array}$ & 10 & 11.30 & 12.13 & 12.75 & $\begin{array}{l}\text { Hypotheti } \\
\text { cal < } \\
\text { Empirica } \\
1\end{array}$ \\
\hline $\begin{array}{l}\text { Social } \\
\text { Attitude } \\
\text { s }\end{array}$ & 10 & 11.01 & 11.37 & 12 & $\begin{array}{l}\text { Hypothe } \\
\text { tical < } \\
\text { Empiric } \\
\text { al }\end{array}$ \\
\hline $\begin{array}{l}\text { Persona } \\
\text { l } \\
\text { Satisfact } \\
\text { ion }\end{array}$ & 10 & 10.63 & 11.17 & 10.36 & $\begin{array}{l}\text { Hypothe } \\
\text { tical < } \\
\text { Empiric } \\
\text { al }\end{array}$ \\
\hline
\end{tabular}

According to the table VIII, empirical mean of three adolescents developmental phase is greater than the hypothetical; its means that the social adjustment of research subjects aged 11-21 years was higher than the population of 11-21 year olds.

3. The mean comparison of research data based on gender

The following describes the way of research subjects based on gender: 
Table IX. The mean comparison of research data based on gender

\begin{tabular}{|l|l|l|l|l|}
\hline $\begin{array}{l}\text { Variable and } \\
\text { Aspect }\end{array}$ & Hypothetical & Male & Female & \multirow{2}{*}{ Comparison } \\
\cline { 3 - 4 } & $(\mathrm{M})$ & $(\mathrm{M})$ & \\
\hline $\begin{array}{l}\text { Social } \\
\text { Adjustment }\end{array}$ & 40 & 44.89 & 44.59 & $\begin{array}{l}\text { Hypothetical } \\
<\text { Empirical }\end{array}$ \\
\hline $\begin{array}{l}\text { Real } \\
\text { Appearance }\end{array}$ & 10 & 10.59 & 10.2 & $\begin{array}{l}\text { Hypothetical } \\
<\text { Empirical }\end{array}$ \\
\hline $\begin{array}{l}\text { Adjustments } \\
\text { Group }\end{array}$ & 10 & 11.84 & 11.69 & $\begin{array}{l}\text { Hypothetical } \\
<\text { Empirical }\end{array}$ \\
\hline $\begin{array}{l}\text { Social } \\
\text { Attitudes }\end{array}$ & 10 & 11.52 & 11.75 & $\begin{array}{l}\text { Hypothetical } \\
<\text { Empirical }\end{array}$ \\
\hline $\begin{array}{l}\text { Personal } \\
\text { Satisfaction }\end{array}$ & 10 & 11.02 & 10.79 & $\begin{array}{l}\text { Hypothetical } \\
<\text { Empirical }\end{array}$ \\
\hline
\end{tabular}

Based on table IX, the variables of social adjustment, the empirical mean in adolescent boys and girls is greater than the hypothetical; it means that the social adjustment is higher than in a population in general. In the aspect of real appearance, the adjustment group, social attitudes and personal satisfaction, the empirical mean of boy and girl is greater than the hypothetical; it means that aspect of real appearance, the adjustment group, social attitudes and personal satisfaction are higher than in population.

Categorization social adjustment based on gender:

Table X. Social Adjustment Subject Categorization based on Gender

\begin{tabular}{|c|c|c|c|c|}
\hline Group & Formula & Categorization & Amount & $\begin{array}{c}\text { Percentage } \\
(\%)\end{array}$ \\
\hline \multirow{3}{*}{ Girl } & $x<32$ & Low & 0 & 0 \\
\hline & $\begin{array}{l}32 \leq X< \\
48\end{array}$ & Average & 61 & 73.5 \\
\hline & $X \geq 48$ & High & 22 & 26.5 \\
\hline \multicolumn{3}{|l|}{ TOTAL } & 83 & 100 \\
\hline
\end{tabular}

Table X, cont.

\begin{tabular}{|l|l|l|l|l|}
\hline \multirow{3}{*}{ Boy } & $\mathrm{X}<32$ & Low & 0 & 0 \\
\cline { 2 - 5 } & $\begin{array}{l}32 \leq \mathrm{X}< \\
48\end{array}$ & Average & 56 & 71.8 \\
\cline { 2 - 5 } & $\mathrm{X} \geq 48$ & High & 22 & 28.2 \\
\hline TOTAL & & 78 & 100 \\
\hline
\end{tabular}

Based on table $\mathrm{X}$, on the subject of girl, none of which have a low social adjustment, 61 are in the medium, and 22 are in the high category. While for the boy, there is no subject in low social adjustment, 56 are in the medium, and 22 are in the high category.

Categorization social adjustment based on adolescent development phase:

Table XI. Social adjustment subject categorization based on adolescent development phase

\begin{tabular}{|c|c|c|c|c|}
\hline Group & Formula & Categorization & Amount & $\begin{array}{c}\text { Percentage } \\
(\%)\end{array}$ \\
\hline \multirow{3}{*}{$\begin{array}{l}\text { Early } \\
\text { Adolescent }\end{array}$} & $X<32$ & Low & 0 & 0 \\
\hline & $\begin{array}{l}32 \leq X< \\
48\end{array}$ & Average & 43 & 78.2 \\
\hline & $X \geq 48$ & High & 12 & 22.8 \\
\hline \multicolumn{3}{|l|}{ TOTAL } & 55 & 100 \\
\hline \multirow{3}{*}{$\begin{array}{l}\text { Middle } \\
\text { Adolescent }\end{array}$} & $X<32$ & Low & 0 & 0 \\
\hline & $\begin{array}{l}32 \leq X< \\
48\end{array}$ & Average & 46 & 74.2 \\
\hline & $X \geq 48$ & High & 16 & 25.8 \\
\hline \multicolumn{3}{|l|}{ TOTAL } & 62 & 100 \\
\hline \multirow{3}{*}{$\begin{array}{l}\text { Late } \\
\text { Adolescent }\end{array}$} & $X<32$ & Low & 0 & 0 \\
\hline & $\begin{array}{l}32 \leq X< \\
48\end{array}$ & Average & 27 & 61.4 \\
\hline & $X \geq 48$ & High & 17 & 38.6 \\
\hline \multicolumn{3}{|l|}{ TOTAL } & 44 & 100 \\
\hline
\end{tabular}

Based on table XI, on the subject early adolescent, none of them have a low social 
adjustment, 43 are in the medium, and 12 are in the high category. While for a group of middle adolescent have no low social adjustments, 46 are in the medium and 16 are in the high category. As for the late teens, none of them have a low social adjustment, 27 are in the medium, and 17 are in the high category.

This study gives an overview of adolescent social adjustment in Special-Needs school in City of Medan. The results of data analysis showed that the moderate category is the majority of deaf adolescent social adjustment. This is in accordance with the opinion of Hurlock (1997), that when the adolescent is able to perform the role effectively socialized, then he will have a good social adjustment. However, some teenagers with hearing impairment is considered less able to adjust effectively in their environment. It can be caused by several factors, such as the acceptance of the social environment, school environment, and a variety of communication styles. This condition ultimately leads to a variation of social adjustment in adolescents with hearing impairment.

Schneiders (1964) explains that social adjustment includes adjustments in the home, school and community adjustment. Social adjustment at home is the first individual social experience. Social adjustment in school is an extension of social adjustment of adolescents to learn to recognize the wider social environment again, is called society. Social adjustment at school characterized by their ability and willingness to learn, accept the authority of teachers, participate in school activities, and is responsible for its work, and is willing to cooperate and help his friend. While social adjustment in the community are more complex. Good social adjustment in society characterized by respect for the rights of others, the ability to cooperate with others, concern for others, and a willingness to help, as well as adherence to the values and norms prevailing in society.

From the results of additional analysis, social adjustment in adolescents with hearing impairment can be classified by range of age, and the data showed that there was no significant difference between adolescent social adjustment Deaf is in the range early teens to late adolescence phase. Although the theory of Schneiders (1964) said that normally with age, a person will also be more mature in response displays related to patterns of social adjustment. One of the factors that can affect a person's social adjustment is the development and maturation; response shown a person will develop through learning and experience which will be closely linked to the process of adjusting itself to its environment.

In addition, social adjustment in adolescents with hearing impairment based on gender, there is little difference between adolescent social adjustment between deaf female and male. Apparently, the social adjustment of hearing impairment female adolescents better than male. This can be caused by the differences in the treatment of women and men in society. Men are generally more active, more independent and tend to be more lax in opposing the rules and norms of society, while women are generally more accustomed to following the norms that will be easier to adapt in their social environment (Papalia, Old \& Feldman, 2008).

\section{CONCLUSIONS}

Based on the research result, known that in general, social adjustment profile adolescence with hearing impairment in Special-Needs School in City of Medan was ranged in middle category. From the results of additional data, in terms of adolescence developmental phase and gender illustrate that the social adjustment adolescence with hearing impairment in Special-Needs School in City of Medan also ranged in middle category.

\section{REFERENCES}

Azwar, S. (1999). Preperation of the scale of psychology, Jakarta: Pustaka Pelajar.

Efendi, Mohammad. (2006). Psikopedagogik introduction of children with disabilities. Jakarta: Bumi Aksara.

Hadi, S. (2000). Research Metodology, Published by: Andi, Yogyakarta

Halllahan, D., P., Kauffman, J., M., Pullen, P. C (2002) Exceptional Learners: An Inttroduction to special Education (12th ed). Boston, Pearson Education, Inc.

Heryati, E. (2010). Psychological needs profile of Adolescent with hearing Impairmant. Bandung: PLB UPI.

Hurlock. E. B. (1997). Developmental psychology: study of life-span development. Jakarta: Erlangga.

Monks, et all. (2006). Developmental psychology.Yogyakarta: Gadjah Mada University. Papalia, D. E, Old, S. W \& Feldman, R. D. (2008).

Human Development (9th Edition). New York: McGraw-Hill, Inc. 
Putra, Hendra. (2013). Bina learning influence the perception of sound and rhythm to the development of communication and autonomy child with hearing impairment in SLB B YPPLB. Ngawi. Retrived Oktober 2016. http://www.scribd.com.
Sastrawinata, E., Salim, M. \& Sugiarto M. H. (1977). Education for children with hearing impairment at SGPLB. Jakarta. Depdikbud.

Schneiders, A. (1964). Personal adjustment and mental health. New York: Rinehart \& Winston.

Somantri, S. (2007). Psychology of child disabilities. Bandung: PT Refika Aditama. 